\title{
ДЕЯТЕЛЬНОСТЬ МЕЖДУНАРОДНОЙ ФЕДЕРАЦИИ ИНЖЕНЕРОВ КОНСУЛЬТАНТОВ (FIDIC) ПО РАЗРАБОТКЕ ТИПОВЫХ ДОГОВОРОВ КАК МЕХАНИЗМ СБЛИЖЕНИЯ НАЦИОНАЛЬНЫХ ПРАВОВЫХ СИСТЕМ
}

\begin{abstract}
Аннотация. Объектом исследования является организация и функиионирование Международной федерации инженеров консультантов (FIDIC) по созданию и поддержанию профессиональных стандартов в области инженерно-строительной деятельности, в том числе, создание норм и правил профессиональной этики, принципов устойчивого развития и т.п. Предметом исследования является деятельность Международной федерачии инженеров-консультантов (FIDIC) по созданию типовых договоров на выполнение работ и оказание услуг в области реализации международных инвестиционно-строительных проектов, которые представляют собой обобщение деловых обыкновений. В ходе исследования применяются общенаучные и частнонаучные методы: методы анализа и синтеза, формально-юридчческий метод. Основной вывод, сделанный в работе заключается в том, что деятельность Международной федерации инженеров консультантов (FIDIC) по систематизации деловых обыкновений, применяемых в области инвестиционно-строительной деятельности, не является ни унификацией, ни гармонизацией права, а представляет собой особый, самостоятельный механизм сближения национальных правовых систем.
\end{abstract}

Ключевые слова: FIDIC, Унификация права, Гармонизация права, Деловые обыкновения, типовые договоры, Инвестиционно-строительная деятельность, Договоры подряда, Договоры оказания услуг, Договор совместной деятельности, Договор на представительство. Abstract: The object of this research is the organization and work of the International Federation of Consulting Engineers (FIDIC) on creation and support of the professional standards in the area of engineering construction activity, including the establishment of norms and rules of professional ethics, principles of sustainable development, etc. The subject of this research is the work of the International Federation of Consulting Engineers on creation of standard contracts for performance of work and provision of services in the area of international investment construction projects, which represent generalization of business practices. The main conclusion consists in the fact that the work of FIDIC on systematization of business practices used in the field of investment construction activity is not a unification or harmonization of law, but rather represents a special, independent mechanism of converging national legal systems.

Keywords: Representation contract, Partnership contract, Service contract, Construction contract, Investment construction activity, Standard contracts, Business practices, Harmonization of law, Unification of law, FIDIC.

ажным направлением межгосударственного сотрудничества в правовой сфере является унификация и гармонизация национального права. Благодаря этой деятельности создается единообразная система правовых предписаний, являющаяся залогом предсказуемости правовых режимов и предпосылкой эффективного сотрудничества государств во всех сферах жизнедеятельности современного общества. 
Авторы монографии «Современное международное частное право в России и Евросоюзе» рассматривают унификацию и гармонизацию как два самостоятельных механизма сближения национальных правовых систем, которые различаются по «степени идентичности устанавливаемых при этом правовых предписаний» [5]. В результате унификации создаются единые международно-правовые нормы, характеризующиеся прямым действием и единым подходом к толкованию. Результатом гармонизации является создание в национальном праве сходных правовых норм, степень идентичности и подходы к толкованию которых могут различаться. Сходствами же унификации и гармонизации является создание правовых норм, т.е. «общеобязательных правил социального поведения, установленных и санкционированных государством, выраженных публично в формально-определенных предписаниях, обычно в письменной форме, и охраняемых органом государства путем контроля за его соблюдением и применения предусмотренных законом мер принуждения за правонарушения» [3; с. 557].

Однако приведенные взгляды на природу и соотношение унификации и гармонизации национального права не являются общепринятыми. Так в работах Н.Г. Дорониной указывается, что гармонизация является разновидностью унификации [1; 2]. Другие авторы отходят от взгляда на унификацию и гармонизацию как на процессы сближения национального права разных стран и обосновывают существование гармонизации национального права, с одной стороны, и международного права, с другой [4]. Таким образом, вопрос о механизмах сближения национальных правовых систем является сложным и неоднозначным, что обусловлено многогранностью права как системы регулирования общественных отношений, а также много- образием социальных норм, за которыми признается юридическое значение.

Например, многие национальные правопорядки признают юридическое значение за деловыми обыкновениями, которые хотя и не являются правовыми нормами, но применяются в качестве субсидиарных регуляторов общественных отношений, входящих в сферу правового регулирования. Деловые обыкновения, как и правовые нормы, развиваются по пути сближения. Деятельность по созданию единообразных международных обычаев и деловых обыкновений представляет собой специфичный механизм сближения национальных правовых систем, не сводимый ни к унификации, ни к гармонизации национального права. Рассмотрим действие данного механизма сближения национального права на примере деятельности Международной федерации инженеров консультантов (FIDIC) по созданию типовых договоров и соглашений.

Краткая характеристика организации и деятельности Международной федерации инженеров консультантов (FIDIC). Международная федерация инженеров консультантов (далее - Федерация, FIDIC) - это неправительственная международная организация, созданная в 1913 году инициативной группой инженеров - представителей трёх стран (Франции, Бельгии и Швейцарии). Поскольку общим языком первых участников Федерации был французский язык, Федерация имеет основное название и аббревиатуру на языке своих создателей (Fédération Internationale Des Ingénieurs-Conseils - FIDIC). В настоящее время в состав Федерации входят ассоциации инженеров-консультантов из 99 стран Европы, Ближнего Востока, Северной и Южной Америки, а также Азии.

Правовой основой деятельности Федерации является Статут FIDIC [6]. В настоящее время действует Статут, приня- 
тый Генеральной Ассамблеей Федерации в 2005 г. в Пекине (в редакции, принятой Генеральной Ассамблеей Федерации в Риоде-Жанейро в 2014 году). Статут определяет цели деятельности Федерации, общие требования к претендентам на вступление в её состав и порядок приобретения статуса её участника, а также систему органов управления Федерацией. Членами FIDIC являются не государства, а национальные ассоциации представителей инженерно-консультационной индустрии. Российским участником FIDIC является Российская ассоциация инженеров консультантов.

Структура Федерации включает в себя Президента Федерации, Вице-президента Федерации, входящих в состав Исполнительного комитета (Executive Committee), семь отраслевых комитетов (Комитет по вопросам членства (Membership Committee), Комитет по вопросам устойчивого развития (Sustainable Development Committee), Комитет по вопросам деловой этики (Integrity Management Committee), Комитет по вопросам договоров (Contract Committee) и др.), Рабочие группы (Task Groups), а также Секретариат, которым руководит Управляющий Директор. Высшим органом управления Федерации является Генеральная Ассамблея. Обратим внимание на следующее обстоятельство: единственным подразделением Федерации, в котором работают наемные работники, получающие денежное вознаграждение, является Секретариат, находящийся в штаб-квартире Федерации, в Швейцарии. Участие в работе иных подразделений Федерации (Комитетах, Рабочих группах) осуществляется на добровольной и безвозмездной основе, т.е. не предполагает получение денежного вознаграждения.

Структура Федерации обусловлена направлениями её деятельности. Так Комитет по вопросам устойчивого развития осу- ществляет мероприятия по созданию системы управления строительными проектами на основе принципов устойчивого развития. В рамках данного направления деятельности, в 2004 году был опубликован «Проект устойчивого управления», ориентирующий подрядные компании, реализующие строительные проекты на учет факторов, влияющих на жизнедеятельность человека и общества в целом (экология, сбережение ресурсов, в том числе трудовых и др.) [7]. В Проекте разработаны критерии, рекомендуемые в качестве индикаторов для оценки качества реализации международных строительных проектов.

Комитет по вопросам деловой этики осуществляет создание системы корпоративных норм поведения субъектами инженерно-консультационной индустрии. В рамках данного направления деятельности Федерации, в 2001 - 2002 году были опубликованы доклады о системе управления на основе норм деловой этики (Business Integrity Management System) [8]. Это, своего рода, свод этических принципов взаимодействия инженера-консультанта и клиента. Федерация ориентирует консалтинговые компании на применение указанных принципов в своей деятельности. Соблюдение этих корпоративных стандартов поведения является необходимой предпосылкой для вступления в Федерацию.

Остановимся более подробно на организации и деятельности Комитета по вопросам договоров. Комитет включает в себя пять участников и пять специальных консультантов, которые назначаются решением Исполнительного комитета. Комитет руководит деятельностью одиннадцати Рабочих групп, каждая из которых работает над проектами отдельных типовых договоров или соглашений, группой типовых договоров/ соглашений или руководствами по применению типовых договоров/ соглашений. Например, Рабочая группа № 1 
разработала «Условия договора на проектирование, строительство и эксплуатацию» (Золотая книга 2008 года); Рабочая группа № 2 разработала Руководство по процедурам материально-технического снабжения, опубликованное в 2011 году; Рабочая группа № 6 работает над созданием новых редакций договоров, опубликованных Федерацией в 1999 году [9].

В состав Рабочих групп входят общепризнанные высококвалифицированные специалисты - инженеры и юристы. Большинство участников Рабочих групп имеют как инженерно-техническое, так и юридическое образование и обладают опытом практической деятельности в качестве руководителей проектов, инженеров, экспертов, арбитров.

За время своего существования Комитет по вопросам договоров проделал масштабную работу по унификации деловых обыкновений и практик, результаты которых нашли отражение в публикациях типовых договоров и соглашений FIDIC.

Регулятивная природа и система типовых договоров и соглашений Международной федерации инженеров консультантов (FIDIC). По мнению автора, сопоставление признаков типовых договоров FIDIC с источниками гражданско-правового регулирования, признаваемыми отечественным правом, позволяет квалифицировать их как деловые обыкновения. Типовые договоры FIDIC не имеют нормативной природы, поскольку применяются не в силу факта своего существования как сложившегося в определенной сфере деятельности и широко применяемого правила поведения. Их применимость и обязательность зависит от прямого, совместного волеизъявления участников договорных отношений в сфере реализации инвестиционно-строительных проектов.

Первая «кодификация» строительных деловых обыкновений была осуществлена
Федерацией в 1957 году, когда был опубликован типовой договор «Условия договоров на выполнение работ в области гражданского строительства» или Красная книга. Эта типовая форма периодически обновлялась и была переиздана четырежды: в 1963, 1977, 1987 и 1999 году.

Значительным событием в разработке типовых договоров FIDIC стало опубликование четырех базовых типовых договоров в 1999 году. Основой «кодификации» 1999 г. является «Краткая форма договора» или Зелёная книга 1999 г. На базе Зелёной книги были разработаны «Условия договора подряда на строительные и инжиниринговые работы, выполняемые по проекту заказчика» или Красная книга 1999 г. и «Условия договора подряда на работы по проектированию, строительству и монтажу, выполняемые по проекту подрядчика» или Жёлтая книга 1999 г. И, наконец, на базе Красной и Жёлтой книг были разработаны «Условия договора подряда для проектов «под ключ»или Серебряная книга 1999 г.

Каждый из названных типовых договоров FIDIC рассчитан на применение к отдельным видам строительных проектов. Так, Красная книга применяется для регулирования строительства, выполняемого на основе проекта заказчика; Жёлтая книга - для регулирования отношений по проектированию и строительству, осуществляемым иждивением подрядчика; Серебряная книга - для регулирования реализации проектов «под ключ» (как самостоятельных, так и в качестве элемента проектов BOT (Build - Operate - Transfer), в которых существенными для инвестора являются четкий срок ввода объекта в эксплуатацию, а также фиксированный бюджет проекта; Зелёная книга рассчитана на применение в проектах с небольшими по стоимости и объёмам работами. 
Результаты «кодификации» 1999 г. легли в основу разработки последующих типовых договоров. В 2006 году были опубликованы «Условия договоров подряда на дноуглубительные и мелиоративные работы» или Сине-зеленая книга 2006 г., а также первое издание гармонизированных «Условий договоров подряда на строительные и инжиниринговые работы, выполняемые по проекту заказчика» или Розовая книга 2006 г., разработанные под эгидой Многостороннего банка развития. В 2008 году Федерация опубликовала «Условия договора на проектирование, строительство и управление» или Золотую книгу 2008 г.; в 2010 годы была введена в действие вторая редакция Розовой книги, а в 2011 году - «Условия субподрядного договора на строительные и инжиниринговые работы, выполняемые по проекту заказчика». Сине-зеленая книга 2006 г. призвана регулировать отношения по выполнению специфических строительных работ в рамках инфраструктурных инвестиционно-строительных проектов по созданию объектов капитального строительства связанных с водными объектами. Розовая книга вобрала в себя обычаи и деловую практику не только в области строительства, но и в области инвестиционно-финансовой деятельности: в ней отражены стандарты, которым должны соответствовать проекты, претендующие на финансирование за счет средств организаций, входящих в Многосторонний банк развития. Золотая книга 2008 года предназначена для регулирования реализации проектов ВОТ (Build-Operate - Transfer): длительных проектов, предполагающих не только создание объекта капитального строительства, но и его обслуживание, а также эксплуатацию после строительства. Субподрядный договор стал ответом на негативную практику некоторых подряд- чиков, которые входя в проект на основании Красной книги 1999 г. или Розовой книги, привлекали субподрядчиков для выполнения отельных работ на основании субподрядных договоров, содержательно не соответствующих принципам и условиям типовых договоров FIDIC, что приводило к нарушениям условий Красной и Розовой книг.

Помимо типовых договоров Федерация разрабатывает типовые соглашения, которые предназначены для регулирования отношений, сопровождающих проектирование и строительство. К типовым соглашениям FIDIC относятся следующие документы: «Типовое соглашение между клиентом и консультантом на оказание услуг» или Белая книга 2006 года; «Субконсультационное соглашение» 1992 года; «Соглашение о совместной деятельности (консорциуме)» 1992 года; «Типовое соглашение на представительство» 2013 года. Указанные типовые соглашения FIDIC предназначены для регулирования различных вариантов взаимодействия между участниками подрядных договоров, с одной стороны, и инженерами-консультантами, инвесторами, посредниками, с другой стороны, по оказанию консультационных и инжиниринговых услуг (в том числе услуг по осуществлению управления проектами, оказываемыми в соответствии с условиями Красной и Желтой книг 1999 г.), услуг представительства, а также по совместной деятельности.

В целях единообразного применения типовых договоров и типовых соглашений участниками международных инвестиционно-строительных проектов, специалистами Комитета по вопросам договоров и Рабочими группами Комитета разрабатываются Руководства, содержащие рекомендации по применению типовых договоров и соглашений FIDIC. Базовым документом данной группы является «Руководство к договорам 
FIDIC для строительства; проектирования, строительства и монтажа; проектов «под ключ», опубликованное в 2000 году. В указанной публикации содержаться рекомендации по применению Красной, Жёлтой и Серебряной книг. Федерацией также разработаны и опубликованы «Руководство по менеджменту качества» 2001 г., «Руководство по процедурам закупок» 2011 г., а также Краткое руководство по управлению рисками.

Выводы. Деятельность Международной федерации инженеров консультантов по систематизации деловых обыкновений в области инвестиционно-строительной деятельности не является унификацией или гармонизацией национального права. Несомненно, обобщение и систематизация деловых обыкновений в области строительства сходна с деятельностью по унификации права: Федерация не просто публикует единообразные деловые обыкновения в формате типовых договоров и соглашений, но и стремится обеспечить их единообразное толкование, путем разработки и издания соответствующих Руководств. Однако есть и существенное отличие, касаю- щееся результатов деятельности Федерации: условия типовых договоров и соглашений FIDIC не являются нормами права (курсив автора - B.B.).

Деятельность FIDIC по опубликованию деловых обыкновений в форме типовых договоров и соглашений - это специфический механизм сближения национальных правовых систем, который минуя нормативный компонент национальной правовой системы (в результате этой деятельности не создаются единообразные нормы права), воздействует на её функциональный компонент. Путем создания единообразных деловых обыкновений и их закрепления в виде условий типовых договоров и соглашений, FIDIC создает предпосылки для их выбора и применения участниками международных строительных проектов, имеющими разную национальную принадлежность, что является предпосылкой единообразия правоприменительной практики по регулированию договорных отношений, рассмотрению споров из указанных отношений в условиях различных национальных правовых систем.

\section{Библиография:}

1. Доронина Н.Г. Унификация и гармонизация права в условиях международной интеграции // Журнал российского права. 1998. № 6. с. $53-55$.

2. Доронина Н.Г. Гармонизация права как альтернатива наднациональности в правовом регулировании экономических отношений // Журнал российского права. 2013. № 10. с. 134 - 138.

3. Общая теория государства и права. Академический курс в трёх томах. Т. 2 / отв. Ред. М.Н. Марченко. M., 2007. $528 \mathrm{c}$.

4. Пшеничнов М.А., Корейво Е.В. Российское законодательство и международное право: юридико-технические средства гармонизации // Международное публичное и частное право. 2006. № 3. с. 45 - 47.

5. Современное международное частное право в России и Евросоюзе: монография / А. Алиев, Ю. Базедов, М.П. Бардина и др.; под ред. М.М. Богуславского, А.Г. Лисицына-Светланова, А. Трунка. М., 2013. 655 с.

6. Statutes and By-Laws International Federation of Consulting Engineers. 19 р.[Электронный ресурс]: Режим доступа: http://fidic.org/sites/default/files/FIDIC\%20Statutes_2014_0.pdf.

7. Project Sustainability Management 8 p.[Электронный ресурс]: Режим доступа: http://www.fidic.org.

8. Guidelines for Business Integrity Management in the Consulting Industry. 2001. 21 р. [Электронный реcypc]: http://www.fidic.org;

9. Business Integrity Management System Training Manual. 2002. 18 p. // http://www.fidic.org.

10. Fahey S., Zahohyi Z. FIDIC Main Contracts - An Overview // Conference Documentation of the FIDIC Asia-Pacific FIDIC Contract Users' Conference. Shenzhen. 2014.5 p. 


\section{References (transliterated):}

1. Doronina N.G. Unifikatsiya i garmonizatsiya prava v usloviyakh mezhdunarodnoi integratsii // Zhurnal rossiiskogo prava. 1998. № 6. s. 53 - 55 .

2. Doronina N.G. Garmonizatsiya prava kak al'ternativa nadnatsional'nosti v pravovom regulirovanii ekonomicheskikh otnoshenii // Zhurnal rossiiskogo prava. 2013. № 10. s. 134 - 138.

3. Pshenichnov M.A., Koreivo E.V. Rossiiskoe zakonodatel'stvo i mezhdunarodnoe pravo: yuridiko-tekhnicheskie sredstva garmonizatsii // Mezhdunarodnoe publichnoe i chastnoe pravo. 2006. № 3. s. 45 - 47.

4. Fahey S., Zahohyi Z. FIDIC Main Contracts - An Overview // Conference Documentation of the FIDIC Asia-Pacific FIDIC Contract Users' Conference. Shenzhen. 2014.5 p. 